\title{
Fragility syndrome: determinant factors in institutionalized elderly
}

Síndrome de fragilidade: fatores determinantes em idosos institucionalizados

Síndrome de fragilidad: factores determinantes en personas institucionalizadas

Daniela Fonseca SILVA ${ }^{1}$

Roberta Almeida ALVES ${ }^{1}$

Thomas Fernando Coelho PESAVENTO

Manoela VILARINHO ${ }^{3}$

Império LOMBARDI JÚNIOR ${ }^{4}$

Vania Fernanda Clemente AGNER ${ }^{1}$

${ }^{1}$ Curso de especialização em saúde do idoso, Universidade Federal de São Paulo, 11015-020, Santos - SP, Brasil

${ }^{2}$ Programa de pós-graduação em Saúde Baseada em evidências, Universidade Federal de São Paulo, 04023-062, São Paulo-SP, Brasil

${ }^{3}$ Faculdades Metropolitanas Unidas, 04112-002, São Paulo-SP, Brasil

${ }^{4}$ Departamento de Ciências do Movimento Humano, Universidade Federal de São Paulo, 11015-020, Santos-SP, Brasil

\section{Abstract}

The aim of the study was to evaluate the frailty syndrome in residents of a Long-Term Care Facility for the Elderly. A crosssectional study was carried out on 24 subjects over the age of 60 years. For the screening of frailty syndrome, the criteria of the Cardiovascular Study were used, which classifies the subjects into fragile, pre-fragile and non-fragile according to five criteria: decreased handgrip strength; self-reported fatigue; decrease in walking speed; unintentional weight loss; and low level of physical activity. The average age of the population studied was 81.13 years, with $54.20 \%$ being female. Among the elderly, $83.33 \%$ were frail, $12.50 \%$ were pre-frail and $4.17 \%$ were not frail. Elderly people over 80 years old had a higher incidence of frailty when compared to those aged 60 - 79 years, with $85.7 \%$ and $80 \%$, respectively. Since $66.67 \%$ of the elderly had decreased handgrip muscle strength, $37.50 \%$ reported fatigue, $41.67 \%$ demonstrated decreased gait speed, $12.50 \%$ unintentional weight loss and $87.50 \%$ were physically inactive. We identified a high prevalence of DES among the elderly residing in the institution studied, thus reinforcing the importance of early screening for frailty in institutionalized elderly.

Descriptors: Aged; Institutionalization; Housing for the Elderly; Frailty.

\section{Resumo}

O objetivo do estudo foi avaliar a síndrome de fragilidade em residentes de uma Instituição de Longa Permanência para Idosos. Foi realizado um estudo transversal em 24 sujeitos com idade superior a 60 anos. Para rastreamento da síndrome de fragilidade foram utilizados os critérios do Estudo Cardiovascular que classifica os sujeitos em frágil, pré-frágil e não frágil de acordo com cinco critérios: diminuição da força de preensão manual; auto-relato de fadiga; diminuição da velocidade de marcha; perda de peso não intencional; e baixo nível de atividade física. A idade média da população estudada foi de 81,13 anos, sendo $54,20 \%$ do sexo feminino. Entre os idosos houve $83,33 \%$ com fragilidade, $12,50 \%$ eram pré-frágeis e $4,17 \%$ não frágeis. Os idosos acima de 80 anos apresentaram incidência maior de fragilidade quando comparados aos de 60 - 79 anos, com $85,7 \%$ e $80 \%$, respectivamente. Sendo que $66,67 \%$ dos idosos apresentaram diminuição da força muscular de preensão manual, 37,50\% relataram fadiga, 41,67\% demonstraram diminuição da velocidade da marcha, $12,50 \%$ perda de peso não intencional e $87,50 \%$ eram inativos fisicamente. Identificamos alta prevalência de SF entre os idosos residentes na Instituição estudada, reforçando assim a importância do rastreamento precoce da fragilidade em idosos institucionalizados.

Descritores: Idoso; Institucionalização; Habitação para Idosos; Fragilidade.

\section{Resumen}

El objetivo del estudio fue evaluar el síndrome de fragilidad en los residentes de un centro de atención a largo plazo para ancianos. Se realizó un estudio transversal en 24 sujetos mayores de 60 años. Para el cribado de síndrome de fragilidad, se utilizaron los criterios del Estudio Cardiovascular, que clasifica a los sujetos en frágiles, pre-frágiles y no frágiles de acuerdo con cinco criterios: disminución de la fuerza del mango; fatiga autoinformada; disminución de la velocidad al caminar; pérdida de peso involuntaria; y bajo nivel de actividad física. La edad promedio de la población estudiada fue de 81.13 años, con un $54.20 \%$ de mujeres. Entre los ancianos, $83.33 \%$ eran frágiles, $12.50 \%$ eran pre-frágiles y $4.17 \%$ no eran frágiles. Las personas mayores de más de 80 años tuvieron una mayor incidencia de fragilidad en comparación con las personas de 60 a 79 años, con $85.7 \%$ y $80 \%$, respectivamente. Dado que el $66.67 \%$ de los adultos mayores había disminuido la fuerza muscular de la empuñadura, el $37.50 \%$ informó fatiga, el $41.67 \%$ demostró una disminución de la velocidad de la marcha, $12.50 \%$ de pérdida de peso no intencional y $87.50 \%$ físicamente inactivo Identificamos una alta prevalencia de DES entre los ancianos que viven en la institución estudiada, lo que refuerza la importancia de la detección temprana de la fragilidad en ancianos institucionalizados.

Descriptores: Anciano; Institucionalización; Viviendas para Ancianos, Fragilidad.

INTRODUCTION

The Fragility Syndrome (FS) is known as a multidimensional geriatric syndrome, which involves biological, psychological and social factors. The human organism becomes unsuccessful in adapting to endogenous and exogenous stressors due to a reserve decrease caused by the progressive decline of the physiological systems ${ }^{1}$.

One of the main issues regarding FS is the elderly's increasing vulnerability. That happens due to the decrease in the muscle resistance, decrease in the neuroendocrine and immunologic systems; and chronic inflammatory state that leads to functional decline, exponentially increasing: elderly dependency, risk of fall, depression symptoms, institutionalization, incapacities, hospitalization and even mortality ${ }^{2}$.

In 2012, a Conference on Consensus About Fragility was held aiming to define diagnostic criteria for FS, thus providing a universal language for its study. During the conference six big international study groups specialized in old age defined the fragility's screening tools. Within these tools is Cardiovascular Health Study (CHS) ${ }^{3}$.

The CHS was developed by Fried et al., using five evaluation criteria to classify the 
elderly in non-fragile, pre-fragile and fragile. This classification is a helpful, ease access and low cost tool that can be used for screening elderly that present risks of developing fragility.

In developed countries, fragility's incidence ranges within $5.8 \%$ and $27.3 \%$, and in developing countries ranges within $26.7 \%$ and $42.6 \%$. In both cases the prevalence screening was done thru CHS. Studies done in Brazil used the same methodology and showed fragility's incidence ranges from $8.7 \%$ to $17.1 \%$ within elderly ${ }^{4}$.

Studies done in Spain, Canada and Poland showed larger FS prevalence in institutionalized elderly, with value that ranged from $29.2 \%$ to $53.7 \%$. Thus, justifying the fact that institutionalized elderly present more comorbidities, higher sedentary and immobilize tendencies ${ }^{2}$.

When comparing institutionalized elderly with ones that live within a community, it can be observed that the former present poorer health.

The institutionalized elderly present a higher number of comorbidities, higher dependency, decrease on functional capacity and on physical aptitude, and tend to develop sedentary habits. All these factors contribute to the increase incidence of pathologies such as sarcopenia and fragility ${ }^{6}$.

Nevertheless, it is of major importance to investigate FS in institutionalized elderly so that the health team can organize more efficient treatment plans that can lead to prevention of possible complications related to the syndrome such as falls, fractures, hospitalization, morbidities, immobilism syndrome and mortality ${ }^{6}$. Thus, this study has as objective to evaluate FS in elderly residents of a Long-term Elderly Institution of philanthropic character in the city of Sao Paulo.

MATERIAL AND METHOD

This cross-sectional study was approved by the Ethics and Research Committee of Brazil's Platform, through Opinion number 2.521.244. The sample was composed of 24 elderly residents of a long-term institution for elderly, situated in the city of Sao Paulo/SP. There were included in the study volunteers that were above 60 years of age and were capable to perform the physical tests whom accepted to participate in the research.

For FS' screening we used the criteria proposed by Fried et al. that proposes five variables are to be evaluated: decrease on hand grip force; self-reported fatigue; decrease in walking speed, unintentional weight loss; and low level of physical activity. And classify the subject in non-fragile, for subjects who do not meet any criteria; pre-fragile, for subjects who meet one or two of the five criteria; and fragile, for subjects who meet three or more criteria.

The muscle strength was evaluated thru grip strength mensuration, for which we used a manual dynamometer of the brand Saeham, model SH5001. The subject was asked to stay in a seated position with feet on the ground, shoulders in neutral position, elbow flexed in 90 degrees' angle and forearm in neutral position. Three measures were taken from each hand, with an interval of 1 minute in between measurement. The highest measurement, of the dominant hand, was considered for the study. Subjects who presented decreased muscle strength adjusted to gender and body mass (BMI) index were included in the frailty criteria.

For the fatigue criteria, we used two selfrelated questions from the Center for Epidemiological Studies - Depression (CES-D) questionnaire. Elderly that answered, "almost always" or "always" for one of the questions were included in the fragility criteria ${ }^{3}$.

The physical performance was evaluated through the Six Minute Walk Test (SMWT), adapted for the institutionalized elderly by the American Alliance for Health, Physical Education, Recreation and Dance (AAHPERD) and validated to the Brazilian population ${ }^{7}$. For the SMWT a walking circuit was set with marks on the floor within every five meters, on the sign of the evaluator, the subject was instructed to follow the marked circuit during 6 minutes, and the walked distance was noted at the end. For safety purpose, chairs were positioned alongside the circuit's route, and an evaluator assisted the subjects by supporting one their arms, still letting the subjects lead to the dislocation. The subjects which presented walking speed below $0.8 \mathrm{~m} / \mathrm{s}$ met the fragility criteria $^{8}$.

The unintentional weight loss was evaluated through subjects' medical records. Individuals who presented weight loss equal to or greater than $4.5 \mathrm{~kg}$ or $5 \%$ of total body weight in the last six months met the frailty criteria.

The physical activity level was evaluated through the International Physical Activity Questionnaire (IPAQ), short version. The questionnaire consisted of 8 questions in an interview format and classified the subjects as very active, active, irregularly active and sedentary. The subjects that classified as irregularly active or sedentary, meaning they reached less than 150 minutes of physical activity per week, met the fragility criteria ${ }^{9}$. 


\section{RESULTS}

The sample was composed by 24 subjects who were 60 years old or older. The mean age was 81.13 years, and the mean institutionalization time was 4.60 years. The men presented higher weight $(59.80 \mathrm{Kg})$ when compared to women $(58.70 \mathrm{Kg})$. As for the mean height, it was the same for men and women, $1.50 \pm 0.10$ meters. Regarding the body mass index, the mean for men was $25.10 \pm 4$ $\mathrm{Kg} / \mathrm{m}^{2}$ and for women is was $25.10 \pm 4.10 \mathrm{Kg} / \mathrm{m}^{2}$. It was noticed the predominance of females, 13 women (54.20\%) and 11 men (45.8\%) (Table 1).

Table 1. Frequency, mean and standard deviation of the characterization data of the institutionalized elderly: age, institutionalization time, weight, height and body mass index, according to gender and total $(n=24)$

\begin{tabular}{l|l|l|l|l|l|l|l}
\hline Variables & \multicolumn{2}{|c|}{ Men } & \multicolumn{2}{|l|}{ Women } & \multicolumn{2}{|c}{ Total } \\
\hline & $\mathrm{n}$ & Mean (SD) & $\mathrm{n}$ & Mean (SD) & $\mathrm{n}$ & Mean (SD) \\
\hline
\end{tabular} \begin{tabular}{l|l|l|l|l|l|l|}
\hline Age (years) & 11 & $76.91(6.07)$ & 13 & $84.38(7.22)$ & 24 & $81.13(7.61)$ \\
\hline $\begin{array}{l}\text { Institutionalization } \\
\text { time (years) }\end{array}$ & 10 & $4.66(4.36)$ & 13 & $3.92(3.01)$ & 23 & $4.60(0.60)$
\end{tabular} \begin{tabular}{ll|l|l|l|l|l|l} 
time (years) & & & & & & \\
\hline Weight (Kilograms) & 11 & $59.80(12.70)$ & 12 & $58.70(13.30)$ & 23 & $58.70(13.0)$ \\
\hline
\end{tabular} \begin{tabular}{ll|l|l|l|l|l|} 
Height (meters) & 11 & $1.50(0.10)$ & 12 & $1.50(0.10)$ & 23 & $1.50(0.10)$ \\
\hline BMI (Kg/m $\left.\mathbf{m}^{2}\right)$ & 11 & $25.40(3.90)$ & 12 & $25.10(4.10)$ & 23 & $25.10(4.0)$ \\
\hline
\end{tabular} $\mathrm{n}=$ sample; $\mathrm{SD}=$ standard deviation

Analyzing each criterion separately for the FS diagnoses composition: 66.67\% presented decreased muscle strength, being that $12.50 \%$ were unable to perform the test; $45.83 \%$ did not report fatigue on the self-report, although $16.67 \%$ did not understand the question; a decrease in walking speed was observed in $41.67 \%$ of the elderly within a total of $50 \%$ that realized the test; $87.50 \%$ of the elderly did not present loss weight, while the unintentional weight loss was observed in $12.50 \%$ of the sample; $95.83 \%$ of the elderly presented low level of physical activity (Table 2).

Table 2. Frequency and percentage of hand dominance and fragility classification, according to the criteria by Fried et al. 2001, in institutionalized elderly, according to gender and total $(n=24)$

\begin{tabular}{|c|c|c|c|}
\hline Variables & Men & Women & Total \\
\hline Dominant Hand & n (\%) & n (\%) & n (\%) \\
\hline Right & $8(72.7)$ & $13(100)$ & $21(87.5)$ \\
\hline Left & $1(18.2)$ & 0 & $1(4.2)$ \\
\hline Didnt comprehend & $2(9.1)$ & o & $2(8.3)$ \\
\hline \multicolumn{4}{|c|}{ Dominant Hand Dynamometry } \\
\hline Normal & $2(18.2)$ & $3(23.1)$ & $5(20.8)$ \\
\hline Weak & $7(63.6)$ & $9(69.2)$ & $16(66.7)$ \\
\hline Unable to perform test & $2(18.2)$ & $1(7.7)$ & $3(12.5)$ \\
\hline \multicolumn{4}{|l|}{ Fatigue } \\
\hline No & $4(36.4)$ & $7(53.8)$ & $11(45.9)$ \\
\hline Yes & $4(36.4)$ & $5(38.5)$ & $9(37.5)$ \\
\hline Didn't understand the question & $3(27.3)$ & $\frac{10.7)}{1(7.7)}$ & $4(16.7)$ \\
\hline \multicolumn{4}{|l|}{ Walking Speed } \\
\hline Unable to perform test & $4(36.4)$ & $8(61.5)$ & $12(50)$ \\
\hline Below $0,8 \mathrm{~m} / \mathrm{s}$ & $6(54.5)$ & $4(30.8)$ & $10(41.7)$ \\
\hline Above $0,8 \mathrm{~m} / \mathrm{s}$ & $1(9.1)$ & $1(7.7)$ & $2(8.3)$ \\
\hline \multicolumn{4}{|l|}{ Unintentional Weight Loss } \\
\hline No & $9(81.2)$ & $12(92.3)$ & $21(87.5)$ \\
\hline Yes & $2(18.2)$ & $1(7.7)$ & $3(12.5)$ \\
\hline \multicolumn{4}{|l|}{ Physical Activity Level } \\
\hline Sedentary & $9(81.9)$ & $12(92.3)$ & $21(87.5)$ \\
\hline Irregularly Active & $2(18.2)$ & 0 & $2(8.3)$ \\
\hline Active & 0 & 0 & 0 \\
\hline Very Active & 0 & $1(7.7)$ & $1(4.2)$ \\
\hline \multicolumn{4}{|l|}{ Fragility Score } \\
\hline Non-fragile & 0 & $1(7.7)$ & $1(4.2)$ \\
\hline Pre-fragile & $2(18.2)$ & $1(7.7)$ & $3(12.5)$ \\
\hline Fragile & 9 & 11 & 20 \\
\hline
\end{tabular}

According to the criteria proposed by Fried et al. ${ }^{3}$, the data presented on Table 2 , for FS' diagnoses, $83.33 \%$ of the evaluated elderly were classified as fragile, $12.50 \%$ were prefragile and $4,17 \%$ were non-fragile. As for gender, $84.62 \%$ of women and $81.82 \%$ of men presented fragility. Men presented worse walking condition. According to the walk speed test, $54.55 \%$ of men were below $0.8 \mathrm{~m} / \mathrm{s}$, while $30.77 \%$ of women had their walk speed test results below the cut value.

When we analyze fragility according to age, $80 \%$ of the elderly in between 60 and 79 years of age and $85.71 \%$ of elderly above 80 years of age presented Fragility Syndrome (Table 3 ). The age group above 80 years old presented a higher percentage of fatigue $(42.86 \%)$ than the age group 60-79 years old $(30.00 \%)$. There was a higher percentage of elderly in the age group above 80 years old that could not perform the Six Minute Walk Test $(57.14 \%)$ than the the elderly in the age group $60-79$ years old $(40.00 \%)$. There was also an increase in the unintentional weight loss within the eldest, thus $14.29 \%$ of the elderly with more than 80 years of age presented unintentional weight loss, while $10 \%$ of the $60-79$ years old group. The $80+$ age group presented $92 \%$ of sedentarismo, while the 60-79 age group presented $80 \%$.

Table 3. Frequency and percentage of fragility classification according to Fried et al. (2001), in institutionalized elderly, according to age and total $(\mathrm{N}=24)$

\begin{tabular}{|c|c|c|c|}
\hline Variables & $\begin{array}{l}60-79 \text { years } \\
n=10 \\
n(\%)\end{array}$ & $\begin{array}{l}\text { Above 8o years } \\
n=14 \\
n(\%)\end{array}$ & $\begin{array}{l}\text { Total } \\
\text { n= 24 } \\
\text { n (\%) }\end{array}$ \\
\hline \multicolumn{4}{|l|}{ Hand Dominant Dynamometry } \\
\hline Normal & $2(20)$ & $3(21.4)$ & $5(20.9)$ \\
\hline Weak & $7(70)$ & $9(64.3)$ & $16(66.7)$ \\
\hline Unable to perform & $1(10)$ & $2(14.3)$ & 3 \\
\hline \multicolumn{4}{|l|}{ Fatigue } \\
\hline No & $5(50)$ & $6(42.9)$ & $11(45.9)$ \\
\hline Yes & $3(30)$ & $6(42.9)$ & 9 \\
\hline Didn't understand the question & $2(20)$ & $2(14.3)$ & $4(16.7)$ \\
\hline \multicolumn{4}{|l|}{ Walking Speed } \\
\hline Did not perform & $4(40)$ & $8(57.1)$ & $12(50)$ \\
\hline Bellow o, $8 \mathrm{~m} / \mathrm{s}$ & $5(50)$ & $5(35.7)$ & $10(41.7)$ \\
\hline Above $0,8 \mathrm{~m} / \mathrm{s}$ & $1(10)$ & $1(7.1)$ & 2 \\
\hline \multicolumn{4}{|l|}{ Unintentional Weight Loss } \\
\hline No & $9(90)$ & $12(85.7)$ & $21(87.5)$ \\
\hline Yes & $1(10)$ & $2(14.3)$ & $3(12.5)$ \\
\hline \multicolumn{4}{|l|}{ Physical Activity Level } \\
\hline Sedentary & $8(80)$ & $13(92.9)$ & $21(87.5)$ \\
\hline Irregularly Active & $2(20)$ & 0 & 2 \\
\hline Active & $\mathrm{o}$ & 0 & $\mathrm{o}$ \\
\hline Very Active & 0 & $1(7.1)$ & $1(4.2)$ \\
\hline \multicolumn{4}{|l|}{ Fragility Score } \\
\hline Non-fragile & $\mathrm{o}$ & $1(7.1)$ & $1(4.2)$ \\
\hline Pre-fragile & $2(20)$ & $1(7.1)$ & $3(12.5)$ \\
\hline Fragile & $8(80)$ & $12(85.7)$ & $20(83.3)$ \\
\hline
\end{tabular}

According to Table 4, we can observe that $29.17 \%$ of the elderly sample needed wheelchairs, $29.17 \%$ were independently mobile, $25 \%$ needed assistance from therapist or care giver, $8.33 \%$ used walkers, as $8.33 \%$ used canes. It can also be observed on Table 4, that $40 \%$ of elderly in the $60-79$ age group were independently mobile, while only $21.43 \%$ of elderly on the $80+$ age group were independent. Within the 60-79 age group, only $20 \%$ used wheel chairs, while on the $80+$ age group $35.71 \%$ were wheelchair dependent.

As for the walking speed, it can be observed on table 05 that the mean speed, in meters per seconds, was $0.30 \pm 0.30$ meters per 
second, there was no difference in mean speed within gender. For the distance, measured in meters, the mean was $99.10 \pm 112.50$ meters for men, while for women it was $93.50 \pm 100.60$ meters.

Table 4. Frequency and percentage of the use of a device for locomotion in institutionalized elderly, according to age $(\mathrm{N}=24)$

\begin{tabular}{l|l|l|l}
\hline Variable & $\begin{array}{l}\mathbf{6 0}-\mathbf{7 9} \text { years } \\
\mathbf{n = 1 0}\end{array}$ & $\begin{array}{l}\text { Above 8o years } \\
\mathbf{n = 1 4}\end{array}$ & $\begin{array}{l}\text { Total } \\
\mathbf{n}=\mathbf{2 4}\end{array}$ \\
\hline & $\mathbf{n}(\%)$ & $\mathbf{n}(\%)$ & $\mathbf{n}(\%)$ \\
\hline Independent & $4(40)$ & $3(21.4)$ & $7(29.2)$ \\
\hline Therapist & $2(20)$ & $4(28.6)$ & $6(25)$ \\
\hline Walker & $1(10)$ & $1(7.1)$ & $2(8.3)$ \\
\hline Cane & $1(10)$ & $1(7.1)$ & $2(8.3)$ \\
\hline Wheelchair & $2(20)$ & $5(35.7)$ & $7(29.2)$ \\
\hline $\mathrm{n}=$ sample
\end{tabular}

Table 5. Frequency and percentage of the Six Minute Walk Test adapted for the elderly according to gender $(N=12)$

\begin{tabular}{l|l|l|l|l|l|l}
\hline Variables & \multicolumn{2}{|c|}{ Men } & Women & Motal \\
\hline $\begin{array}{l}\text { Walking speed } \\
\text { (m/s) }\end{array}$ & 7 & $0.30(0.30)$ & 5 & $0.3(0.3)$ & 12 & $0.30(0.30)$ \\
\hline $\begin{array}{l}\text { Displacement } \\
\text { (meters) }\end{array}$ & 7 & $99.10(107.5)$ & 5 & $93.50(93.5)$ & 12 & $99.10(112.5)$ \\
\hline
\end{tabular}

Another finding of the present study was that men were institutionalized for longer periods of time when compared to women, 4.6 years and 3.9 years respectively, which diverges from other studies where women spent more time institutionalized ${ }^{10}$. Although females represent a larger number in institutions, their risk of death is also higher. Women are at higher risk of death when institutionalized ${ }^{10}$ due to greater prevalence of fragility, chronic diseases and depression, which justifies the longer institutionalization time amongst men.

The mean body mass index (BMI) of the elderly participants in the research was 25.10 $\mathrm{kg} / \mathrm{m}^{2}$, this value indicates that most of the elderly were eutrophic, other studies that also included institutionalized elderly showed a mean BMl in between $22.7 \mathrm{~kg} / \mathrm{m}^{2}$ and $27.61 \mathrm{~kg} / \mathrm{m}^{11}$ that corroborates with the findings in this study. However, the BMI is not a good predictor for evaluating nutritional health status. But when using the Mini Nutritional Assessment, 2/3 of the elderly were found to be undernourished or at risk of being undernourished, which can be justified by the increase in morbidities and dependency. In this study, the BMI sample was used as to adjust the muscle strength table and not in evaluating the nutritional health status ${ }^{12}$.

Analyzing the fragility criteria, $66.67 \%$ of the evaluated elderly presented a decrease in muscle force. Studies show that the decrease in muscle strength is one of the first signs of FS and is related to sedentarism, body mass deficit, health problems and functional limitations. These conditions are common both in noninstitutionalized and institutionalized elderly. However, institutionalized elderlies are more often sedentary and, present low weekly caloric expenditure, which contributes to a decrease in muscle strength and slower walking speed ${ }^{13}$.
Nonetheless, women in that study showed an accentuated decrease in muscle strength both due to intrinsic factor (menopausal hormonal changes, increase in adipose tissue and decrease in bone density), as well as extrinsic factors (inadequate food intake and physical inactivity), both which collaborate to decrease in muscle strength ${ }^{14}$.

In the present study, fatigue was reported by $37.50 \%$ of the elderly and was more often in women than in men, $38.46 \%$ and $36.36 \%$ respectively. This if justified by the fact that women happen to be more susceptible to higher rates of body fat, chronic inflammation, decreased physical fitness and depression, all of which favor the presence of fatigue ${ }^{15}$. Fatigue has a strong relationship with depression, a common pathology in institutionalized elderly due to social isolation, different habits, living with strangers and being away from family

In a systematic review on FS in institutionalized elderly, it was observed that between $2.8 \%$ and $8.9 \%$ of the elderly were healthy, values that agree with the findings of this study ${ }^{16}$. This finding can be justified by two main reasons: the search for the Long-term Elderly Institution as an alternative care for the fragile elderly, and on the other hand, the environment promoted by the institution can contribute to the development of fragility, some factors are the predictors of the institutionalization process, being the main ones, age, altered cognition, aggressive behavior, caregiver being overloaded, widowing, development of dementia, development of severe hearing loss, severe depression, mobility issues $^{16}$.

The institutionalized elderly is more exposed to factors that contribute to the loss of their identity and autonomy, social isolation, being away from family, which when associated with increased dependence on daily life activities and diminished functional independency, help in the development of pathological alterations such as loneliness and depression ${ }^{17}$, and the latter contributes directly to FS. Another fact that contributes to the high prevalence of FS in institutionalized elderly is the presence of cognitive disorders, which contribute to decreased mobility and consequently a decrease in muscle mass, strength and changes in body composition ${ }^{18}$.

In this sample, the elderly over 80 years of age had a higher prevalence of fragility, $85.71 \%$. Another finding related to longevity was that among the elderly over 80 years of age, only $21.43 \%$ independently mobile, as $35.71 \%$ used wheelchairs for their mobility. These 
numbers are larger when compared to their peers with age between 60 and 79 years, 40\% and $20 \%$ respectively. In a systematic review, fragility was present among the long-lived elderly, which corroborates our findings ${ }^{19}$. As age progresses, the elderly present a gradual increase in cellular oxidative stress causing damage to the whole organism. Among these damages, we can mention the loss of muscle mass and deregulation in inflammatory processes, which directly imply the development of fragility and functional alterations ${ }^{20,21}$. This justifies the fact that age is a risk factor for fragility, independent of any variable ${ }^{22}$. Aging is aggravated by the presence of functional disabilities and chronic comorbidities common in this population, such as osteoarticular diseases, diabetes, cardiorespiratory diseases, neurological diseases, among others which contribute to decreased mobility within the longlived elderl ${ }^{23}$.

Women also had a higher rate of fragility when compared to men, $84.62 \%$ and $81.82 \%$, which may be justified by the fact that they present dominance in the items that make up the fragility phenotype in this study. Female subjects present a higher incidence of sarcopenia, greater longevity and a higher prevalence of chronic diseases ${ }^{24}$, also a decrease in muscle mass and strength, caused by the postmenopausal hormone decline. Female subjects also present poorer diets and worse sociodemographic conditions ${ }^{25}$, factors that justify the findings of this study.

The screening of the FS provides data for the development of more specific and effective preventive and treatment actions, as well as the creation of public policies aimed at preventing fragility in both the institutionalized and non-institutionalized elderly in the community, since FS also is cited as one of the causes of institutionalization ${ }^{26}$.

When thinking about the institutionalized elderly, we have two distinct aspects related to fragility, the prevention and the treatment. Although the number of fragile elderlies is greater than the elderlies who are in the previous stages, pre-fragile and non-fragile, it is of paramount importance to adopt preventive measures. Thus, considering that the very environment offered by the Long-term Elderly Institutions, associated to the physiological changes due to aging and the presence of several pathologies all facilitate the development of $\mathrm{FS}^{27}$. Regarding the elderly who has already developed fragility, clinical reasoning will be aimed at reducing their vulnerability and stabilizing the syndrome, thus contributing to diminishing the negative health outcomes ${ }^{28}$.

The management of the institutionalized elderly should begin with the application of the Comprehensive Geriatric Assessment (CGA), which is considered as the gold standard for FS management. During the CGA the multidisciplinary team will evaluate the elderly in all its extension, thus will be drawn the best approach for the accompaniment of this subject, be it preventive or curative. Among the objectives of this evaluation, is the diagnosis of all the pathologies, be them physical, cognitive or emotional as well as a review of all medication ${ }^{29}$. According to the findings of this evaluation, the professionals of the multidisciplinary team will have more data and foundation for the creation of strategies that aim the reduction of the present comorbidities.

Within the specific strategies, are the physical rehabilitation program, which presents the rehabilitation of the elderly's musculoskeletal system as a goal and aims to decrease the functional deficit. The program must be applied in an individualized form, respecting individual's particularities. There is an agreement that some elements must be present, such as improvement of cardiovascular system, muscle strength, flexibility and balance. Thus, increasing functional capacity and decreasing sedentarism ${ }^{30}$.

Another strategy is improving the diet and nutrients intake. The diet is a very important and variable factor directly connected to fragility. Malnutrition leads to weight loss which is one of the criteria in the screening for FS. That makes nutritional monitoring essential for reducing the vulnerability and preventing FS. As well as physical rehabilitation, the diet, should respect each elderly's individuality. In such a way that, by promoting a correction in nutritional deficits, a favorable environment for muscle mass gain is created $^{31}$.Diet containing high quality foods, rich in protein, and all micro and macronutrients in adequate quantities, can prevent and treat FS in a proper manner ${ }^{32}$.

CONCLUSION

Despite the modest sample size, we identified high prevalence in the institutionalized elderly. This study verified that the decrease in mobility, muscle strength as well as physical inactivity, are determinant factors for FS' development. These are initial findings that need complement to establish new strategies in the prevention and treatment of chronic diseases in institutionalized elderly.

REFERENCES

1. Subra J, Gillette-Guyonnet S, Cesari M, Oustric 
S, Vellas B, Platform Team. The Integration Of Frailty Into Clinical Practice: preliminary results from the gérontopôle. J Nutr Health Aging. 2012;16(8):714-20.

2. Marchiori GF, Tavares DMS. Mudanças nas condições de fragilidade e componentes fenotípicos em idosos após hospitalização. Rev Lat Am Enfermagem. 2017;25:e2905.

3. Fried LP, Tangen CM, Walston J, Newman AB, Hirsch C, Gottdiener J, et al. Frailty in older adults: evidence for a phenotype. J Gerontol A Biol Sci Med Sci. 2001;56(3):146-57.

4. Vieira RA, Guerra RO, Giacomin KC, Vasconcelos KSS, Andrade ACS, Pereira LSM. Prevalência de fragilidade e fatores associados em idosos comunitários de Belo Horizonte, Minas Gerais, Brasil: dados estudo FIBRA. Cad Saude Pública. 2013;29(8):1631-643.

5. Escuin MR, Vaca JG, Pérez RV, García MDA, Iglesias MS, Carbonell JLO, et al. Frailty and mortality or incident disability in institutionalized older adults: the FINAL study. Maturitas. 2014;18(4):329-34.

6. Mesquita AF, Silva EC, Eickemberg M, Roriz CKA, Medeiros MB, Ramos LB. Factors associated with sarcopenia in institutionalized elderly. Nutr Hosp 2017;34(2):345-51.

7. Benedetti TRB, Mazo GZ, Gonçalves LHT. Bateria de testes AAHPERD: adaptação para idosos institucionalizados. RBCDH. 2014; 16(1):1-14.

8. Alexandre TS, Duarte YA, Santos JL, Wong R, Lebrão ML. Sarcopenia according to the European Working Group on Sarcopenia in Older People (EWGSOP) versus dynapenia as a risk factor for mortality in the elderly. J Nutr Health Aging. 2014;18(8):751-56.

9. Matsudo $S$, Araújo $T$, Matsudo $V$, Andrade $D$, Andrade E, Oliveira LC, et al. Questionário internacional de atividade física (IPAQ): estudo de validade e reprodutilidade no Brasil. Rev Bras Ativ Fís Saúde. 2001;6(2):5-18.

10. Pinheiro NCG, Holanda VCD, Me LA, Medeiros AKB, Lima KC. Desigualdade no perfil dos idosos institucionalizados na cidade de Natal, Brasil. Cien Saude Colet. 2016;12(11): 3399-405.

11. Souza TK, Mesquita LAS, Pereira LA, Azeredo $\mathrm{CM}$. Baixo peso e dependência funcional em idosos institucionalizados de Uberlândia (MG), Brasil. Cien Saude Colet. 2014;19(8):3513-520.

12. Pereira MLAS, Moreira PA, Oliveira CC, Roriz AKC, Amaral MTR, Mello AL, et al. Nutritional status of institutionalized elderly Brazilians: a study with the Mini Nutritional. Nutr Hosp. 2015;31(3):1198-204.

13. Santo CE. Perfil da saúde e qualidade de vida de idosos de uma instituição de longa permanência do município de Bauru, São Paulo [tese]. Bauru/SP: Universidade de São Paulo Faculdade de Odontologia de Bauru; 2014.

14. Silva EC, Roriz AKC, Eickemberg M, Mello AL, Côrtes EBQ, Feitosa CA et al. Factors associated with anemina in the institutionalized elderly. PLoS One. 2016;11(9):e0162240.

15. Martikainen $P$, Moustgaard H, Einio R, Murphy M. Life expectancy in long-term institutional care by marital status: multistate life table estimates for older finnish men and women. $J$ Gerontol B Psychol Soc Sci.2013;69(2):303-10.

16. Pereira AA, Borim FSA, Neri AL. Risk of death in elderly persons based on the frailty phenotype and the frailty index: a review study. Rev bras geriatr gerontol. 2017;20(2):273-85.

17. Pereira IFS, Spyrides MHC, Andrade LMB. Estado nutricional de idosos no Brasil: uma abordagem multinível. Cad Saude Publica. 2016;32(5):e00178814.

18. Raso V, Tolea MI, Mancini RB, Matsudo SMM. Grip strength predicts physical function in nursing home residents. Medical Express. 2017;4(1):M170104.

19. Kojima G. Prevalence of frailty in nursing homes: a systematic review and meta-analysis. J AM Med Dir Assoc. 2015;16(11):940-45.

20. Hajek A, Brettschneider C, Lange C, Pesselt T, Wiese B, Steinmann $S$ et al. Longitudinal predictors of institutionalization in old age. PLoS One. 2015;10(12):e0144203.

21. Mansfield JC, Wirtz PW. Predictors of entry to the nursing home: does length of follow-up matter? Arch Gerontol Geriatr. 2011;53(3): 309-15.

22. Duca GF, Antes DL, Hall PC. Quedas e fraturas entre residentes de instituições de longa permanência para idosos. Rev Bras Epidemiol. 2013;16(1):68-76.

23. Cordeiro LM, Paulino JL, Bessa MEP, Borges CL, Leite SFP. Qualidade de vida dos idosos fragilizados e institucionalizados. Acta Paul Enferm. 2015;28(4):361-66.

24. Reis KMC, Jesus CAC. Cohort study of institutionalized elderly people: fall risk factors. Rev Lat Am Enfermagem. 2015;23(6): 1130-138.

25. de Labra C, Guimaraes-Pinheiro C, Maseda A, Lorenzo T, Millán-Calenti JC. Effects of physical exercise interventions in frail older adults: a systematic review of randomized controlled trials. BMC Geriatr. 2015;15:154.

26. Mello AC, Engstrom EM. Alves LC. Healthrelated and socio-demographic factors associated with frailty in the elderly: a systematic literature review. Cad Saude Publica. 2014;30(6):1143-168.

27. Lenardt MH, Carneiro NHK, Binotto MA, Setoguchi LS, Cechinel C. Relação entre fragilidade física e características 
sociodemográficas e clínicas de idosos. Esc Anna Nery. 2015;19(4):585-92.

28. Yang F, Chen QW. Evaluation of frailty and influencing factors in old people in hospital institution: evidence for a phenotype of frailty. Medicine (Baltimore). 2018;97(3):e9634.

29. Puts MTE, Toubasi S, Andrew MK, Ashe MC, Ploeg J, Atkinson E et al. Interventions to prevent or reduce the level of frailty in community-dwelling older adults: a scoping review of the literature and international policies. Age and Ageing. 2017;46(3):383-392.

30. Tuner G, Clegg A. Best practice guidelines for the management of frailty: a British Geriatrics Society, Age Uk and Royal College of general practitioners. Age and Ageing. 2014;43(6): 744-47.

31. Artabe IA, López OS, Hernández NS, Gutierrez $\mathrm{NF}$, Malafarina $\mathrm{V}$. The relationship between nutrition and frailty: effects of protein intake, nutritional supplementation, vitamin $D$ and exercise on muscle metabolism in the elderly. A systematic review. Maturitas. 2016;93:89-99.

32. López LL, Maseada A, Labra C, Folgueira LR, Villamil JLR, Calenti JCM. Nutritional determinants of frailty in older adults: a systematic review. BMC Geriatr. 2017;17(1):108.

\section{CONFLICTS OF INTERESTS}

The authors declare no conflicts of interests.

\section{CORRESPONDING AUTHOR}

\section{Império Lombardi Júnior}

Departamento de Ciências do Movimento Humano, Universidade Federal de São Paulo,

11015-020 Santos-SP, Brasil

E-mail: imperiolombardi@gmail.com 